\title{
$17 \beta$-Estradiol regulates histone alterations associated with memory consolidation and increases Bdnf promoter acetylation in middle-aged female mice
}

\author{
Ashley M. Fortress, ${ }^{1}$ Jaekyoon Kim, ${ }^{1}$ Rachel L. Poole, ${ }^{2}$ Thomas J. Gould, ${ }^{2}$ \\ and Karyn M. Frick ${ }^{1}$ \\ ${ }^{1}$ Department of Psychology, University of Wisconsin-Milwaukee, Milwaukee, Wisconsin 53211, USA; ${ }^{2}$ Department of Psychology, \\ Temple University, Philadelphia, Pennsylvania 19122, USA
}

\begin{abstract}
Histone acetylation is essential for hippocampal memory formation in young adult rodents. Although dysfunctional histone acetylation has been associated with age-related memory decline in male rodents, little is known about whether histone acetylation is altered by aging in female rodents. In young female mice, the ability of $17 \beta$-estradiol $\left(E_{2}\right)$ to enhance object recognition memory consolidation requires histone $\mathrm{H} 3$ acetylation in the dorsal hippocampus. However, the extent to which histone acetylation is regulated by $E_{2}$ in middle-aged females is unknown. The mnemonic benefits of $E_{2}$ in aging females appear to be greatest in middle age, and so pinpointing the molecular mechanisms through which $E_{2}$ enhances memory at this age could lead to the development of safer and more effective treatments for maintaining memory function without the side effects of current therapies. Here, we show that dorsal hippocampal infusion of $E_{2}$ rapidly enhanced object recognition and spatial memory, and increased histone $\mathrm{H} 3$ acetylation in the dorsal hippocampus, while also significantly reducing levels of histone deacetylase (HDAC2 and HDAC3) proteins. $E_{2}$ specifically increased histone $\mathrm{H} 3$ acetylation at Bdnf promoters pII and pIV in the dorsal hippocampus of both young and middle-aged mice, despite age-related decreases in pI and pIV acetylation. Furthermore, levels of mature BDNF and pro-BDNF proteins in the dorsal hippocampus were increased by $E_{2}$ in middle-aged females. Together, these data suggest that the middle-aged female dorsal hippocampus remains epigenetically responsive to $E_{2}$, and that $E_{2}$ may enhance memory in middle-aged females via epigenetic regulation of $B d n f$.
\end{abstract}

Epigenetic processes such as histone acetylation are essential for memory formation in the hippocampus and other cognitive regions of the brain (Vecsey et al. 2007; Fischer et al. 2010; Sharma 2010; Graff and Tsai 2013a,b; Peixoto and Abel 2013). DNA is supercoiled around four histone proteins $(\mathrm{H} 2 \mathrm{~A}, \mathrm{H} 2 \mathrm{~B}, \mathrm{H} 3$, and $\mathrm{H} 4)$, each of which has an amino acid tail that can be acetylated to relax chromatin structure and increase transcription. Acetyl groups are added to lysines by histone acetyltransferases (HATs) and removed by histone deacetylases (HDACs) (Yang 2007). Considerable evidence suggests that histone acetylation promotes memory formation. For example, hippocampal contextual learning increases H3 acetylation (Levenson et al. 2004), whereas expression of certain HDACs, such as HDAC2 and HDAC3, impairs spatial, contextual, and object recognition memories mediated by the hippocampus (Guan et al. 2009; Haettig et al. 2011; Hawk et al. 2011; McQuown et al. 2011). Furthermore, HDAC inhibitors enhance hippocampal memory, synaptic plasticity, and gene expression in young rodents (Stefanko et al. 2009; Zhao et al. 2010), supporting the notion that histone acetylation facilitates the expression of genes necessary for memory formation.

However, much less is known about the contributions of histone acetylation to memory formation in the aging brain. To date, few studies have examined this issue. In middle-aged mice, impaired spatial and contextual memory has been associated with deficits in learning-induced $\mathrm{H} 4$ acetylation in the hippocampus (Peleg et al. 2010; Dagnas and Mons 2013). Treatment with HDAC inhibitors reverses these deficits in middle-aged mice (Peleg

\section{Corresponding author: frickk@uwm.edu}

Article is online at http://www.learnmem.org/cgi/doi/10.1101//m.034033.113. et al. 2010), which is consistent with other data from middle-aged male rats showing that aging increases HDAC activity in the hippocampus (Dos Santos Sant' Anna et al. 2013). HDAC inhibition can also reverse memory deficits in mouse models of Alzheimer's disease (Kilgore et al. 2010). Although these studies suggest that dysregulated hippocampal histone acetylation in middle age leads to memory impairment, it is notable that none specifically examined histone acetylation in females. The onset of memory decline occurs earlier in female rats and mice than in males, and is associated with the loss of estrous cycling (Markowska 1999; Frick et al. 2000). In the hippocampus of middle-aged females, levels of the primary estrogen receptors $(\mathrm{ER} \alpha$ and $\mathrm{ER} \beta)$ are reduced (Yamaguchi-Shima and Yuri 2007; Bohacek and Daniel 2009), and prolonged ovarian hormone deprivation reduces the ability of the most biologically active estrogen, $17 \beta$-estradiol $\left(\mathrm{E}_{2}\right)$, to regulate estrogen receptor levels (Daniel et al. 2006; Bohacek et al. 2008; Bohacek and Daniel 2009). Nevertheless, exogenous $\mathrm{E}_{2}$ can still reverse hippocampal memory deficits in middle-aged female rodents (Markham et al. 2002; Fernandez and Frick 2004; Bimonte-Nelson et al. 2006; Daniel et al. 2006), demonstrating that the middle-aged hippocampus remains somewhat responsive to $\mathrm{E}_{2}$. Indeed, our laboratory has shown that a bilateral infusion of $\mathrm{E}_{2}$ into the dorsal hippocampus enhances object recognition

(C) 2014 Fortress et al. This article is distributed exclusively by Cold Spring Harbor Laboratory Press for the first 12 months after the full-issue publication date (see http://learnmem.cshlp.org/site/misc/terms.xhtml). After 12 months, it is available under a Creative Commons License (Attribution-NonCommercial 4.0 International), as described at http://creativecommons.org/ licenses/by-nc/4.0/. 
memory in middle-aged female mice in a manner dependent on rapid activation of phosphatidylinositol 3-kinase (PI3K) and extracellular signal-regulated kinase (ERK) (Fan et al. 2010). Given our previous reports in young female mice that bilateral infusion of $\mathrm{E}_{2}$ into the dorsal hippocampus increases histone $\mathrm{H} 3$ acetylation within $30 \mathrm{~min}$ in an ERK-dependent manner (Zhao et al. 2010, 2012), this finding might suggest an important role for $\mathrm{E}_{2}$-induced histone acetylation in memory formation among middle-aged females. The $\mathrm{E}_{2}$-induced increase in $\mathrm{H} 3$ acetylation in young females is blocked by HAT inhibition, as is an $\mathrm{E}_{2}$ -induced decrease in HDAC2 protein $4 \mathrm{~h}$ after infusion (Zhao et al. 2010, 2012). These data suggest that ERK-driven histone acetylation is essential for $\mathrm{E}_{2}$ to regulate memory in young females. However, the extent to which histone acetylation is necessary for $\mathrm{E}_{2}$ to enhance memory in middle age remains unknown, as are the downstream gene targets necessary for $\mathrm{E}_{2}$ to enhance memory at any age.

One potential gene target involved in estrogenic regulation of hippocampal memory consolidation is brain-derived neurotrophic factor (BDNF). BDNF is crucial for synaptic plasticity and hippocampal memory formation (Heldt et al. 2007; Bekinschtein et al. 2014). The Bdnf gene consists of eight untranslated exons and one protein coding exon (Aid et al. 2007). In the hippocampus, BDNF transcripts can be uniquely regulated by L-type calcium channels (Tao et al. 1998) and aging (Chapman et al. 2012; Perovic et al. 2013). Epigenetic regulation of Bdnf in the hippocampus by HDAC inhibition (Koppel and Timmusk 2013) or contextual fear conditioning (Lubin et al. 2008) has also been shown to increase the expression of specific $B d n f$ exons. $\mathrm{E}_{2}$-induced activation of L-type calcium channels increases CREB phosphorylation to promote gene transcription and exert neurotrophic effects in hippocampal neurons (Boulware et al. 2005; Wu et al. 2005; Zhao et al. 2005), and high levels of $E_{2}$ during the estrous cycle are associated with increased hippocampal CA1 excitability in a BDNF-dependent manner (Scharfman et al. 2003). Further, aging and ovariectomy significantly decrease the expression of BDNF mRNA in the hippocampus in rodents (Singh et al. 1995; Sohrabji et al. 1995; Chapman et al. 2012; Perovic et al. 2013). Exogenous $\mathrm{E}_{2}$ administered to ovariectomized rodents (Singh et al. 1995; Sohrabji et al. 1995) or elevated $E_{2}$ in the estrous cycle are associated with increased BDNF mRNA or protein levels (Gibbs 1998; Scharfman et al. 2003). Because $\mathrm{E}_{2}$ modulates many of the same neural mechanisms responsible for epigenetic regulation of $B d n f$, and $E_{2}$ can rapidly activate cell signaling independent of transcriptional genomic mechanisms to enhance hippocampal memory (Packard and Teather 1997b; Fernandez et al. 2008; Zhao et al. 2010), we reasoned that $B d n f$ may be a key gene that is epigenetically regulated by $\mathrm{E}_{2}$.

Here, we demonstrate that the female middle-aged dorsal hippocampus remains epigenetically responsive to $E_{2}$. Our findings suggest that $\mathrm{E}_{2}$ may facilitate memory consolidation in the novel object recognition and object placement tasks by increasing histone $\mathrm{H} 3$ acetylation at Bdnf promoters in the dorsal hippocampus.

\section{Results}

\section{Estradiol enhances novel object recognition and object placement memory consolidation in middle-aged female mice}

We first sought to replicate our previous findings that a posttraining infusion of $5 \mu \mathrm{g}$ of $\mathrm{E}_{2}$ into the dorsal hippocampus of ovariectomized middle-aged female mice enhances novel object recognition (NOR) memory consolidation (Fan et al. 2010). Mice first explored two identical objects until they had accumulated
30 sec of object exploration (Fig. 1A). Immediately after this training, mice received bilateral dorsal hippocampal infusion of vehicle or $5 \mu \mathrm{g}$ of $\mathrm{E}_{2}$. Memory for the training objects was tested $48 \mathrm{~h}$ later by allowing the mice to explore an object identical to that used in training (i.e., familiar) and a novel object. As in our previous work (Fan et al. 2010), middle-aged mice infused with $\mathrm{E}_{2}$ into the dorsal hippocampus immediately post-training spent significantly more time than chance with the novel object $48 \mathrm{~h}$ later $\left(t_{(16)}=3.41, P=\right.$ $0.004)$ (Fig. 1B). In contrast, vehicle-infused mice did not exhibit a significant preference for the novel object $\left(t_{(15)}=-1.56, P=0.14\right)$ (Fig. 1B), suggesting that $E_{2}$ enhanced NOR memory consolidation in middle-aged females. We next determined whether the beneficial effects of dorsal hippocampal $\mathrm{E}_{2}$ infusion in middle-aged females extend to other forms of memory mediated by the hippocampus. The object placement (OP) task tests hippocampaldependent spatial memory, and $\mathrm{E}_{2}$ administered to the dorsal hippocampus immediately after training enhances OP memory consolidation in young female mice (Boulware et al. 2013). In the present study, middle-aged females were trained in the OP task 2 wk after NOR testing (Fig. 1A). The training procedure for OP was identical to that for NOR. Immediately after training, the mice were bilaterally infused with vehicle or $5 \mu \mathrm{g}$ of $\mathrm{E}_{2}$ into the dorsal hippocampus. Twenty-four hours after training, one of the identical objects was moved to a lower corner of the testing arena and mice were again allowed to accumulate 30 sec of exploring the objects. Neither vehicle- nor $\mathrm{E}_{2}$-infused mice showed a significant preference for the moved object in the novel location (data not shown). Because spatial memory decays more rapidly with aging than object memory (Wimmer et al. 2012), we next tested the mice using a shorter 4 -h delay. Indeed, $4 \mathrm{~h}$ after training, mice infused with $\mathrm{E}_{2}$ spent significantly more time than chance with the moved object $\left(t_{(7)}=7.14, P<0.001\right)$ (Fig. 1C), demonstrating an intact memory for the unmoved object. In comparison, vehicle-infused mice did not spend more time than chance with the moved object $\left(t_{(7)}=0.18, P=0.86\right)$ (Fig. 1C). These data show for the first time that acute post-training infusion of $\mathrm{E}_{2}$ into the dorsal hippocampus enhances spatial memory consolidation in middle-aged females, and demonstrate $\mathrm{E}_{2}$ can enhance the consolidation of multiple forms of hippocampal memory in middle age.

\section{Estrogenic effects on histone acetylation are restricted to $\mathrm{H} 3$}

We next determined the extent to which this memory-enhancing dose of $\mathrm{E}_{2}$ triggers epigenetic alterations in the middle-aged dorsal hippocampus. We began with histone acetylation because this process regulates hippocampal memory and the genes necessary for synaptic plasticity (Guan et al. 2009; Graff et al. 2012). Of the four core histones (H2A, H2B, H3, and H4), acetylation of $\mathrm{H} 3$ is particularly important in regulating hippocampal learning and memory (Levenson et al. 2004), as well as estrogenic modulation of learning and memory. We previously found in young female mice that dorsal hippocampal infusion of 5- $\mu \mathrm{g} \mathrm{E} \mathrm{E}_{2}$ significantly increases acetylation of $\mathrm{H} 3$ (but not $\mathrm{H} 2 \mathrm{~B}$ or H4) 30 min later in an ERK-dependent manner, and that histone acetylation is required for $\mathrm{E}_{2}$ to enhance NOR memory consolidation (Zhao et al. 2010, 2012). Because $\mathrm{E}_{2}$ enhances memory consolidation among middle-aged females in a manner similar to young females (Fig. 1; Fan et al. 2010), we hypothesized that $\mathrm{E}_{2}$ would also increase histone acetylation among middle-aged females in an H3-specific manner. Middle-aged mice $(n=27)$ were bilaterally infused into the dorsal hippocampus with vehicle or $5-\mu \mathrm{g} \mathrm{E}_{2}$, and the dorsal hippocampus was collected bilaterally 30 or $60 \mathrm{~min}$ later for Western blot analysis. The 60 -min time point was included in case alterations in histone acetylation were delayed beyond the 

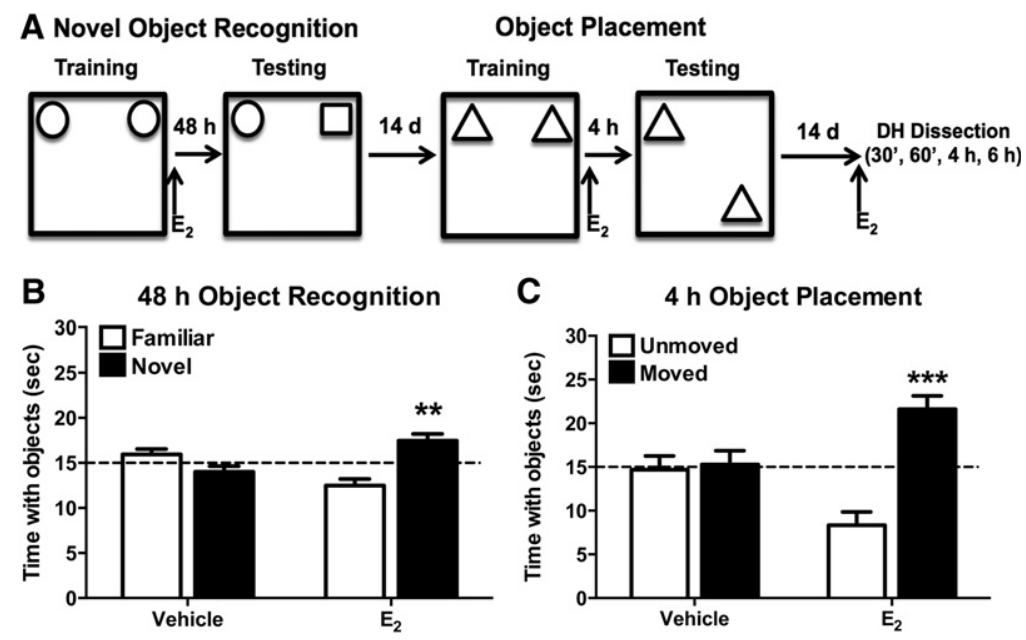

Figure 1. Bilateral dorsal hippocampal $(\mathrm{DH})$ infusion of $\mathrm{E}_{2}$ enhances novel object recognition and object placement memory consolidation. (A) Schematic diagram of the experimental design illustrating the novel object recognition (NOR) and object placement (OP) protocols. In NOR, mice accumulate 30 sec exploring two identical objects and then receive bilateral dorsal hippocampal infusions of $5-\mu \mathrm{g} \mathrm{E}_{2} \mathrm{im}$ mediately post-training. Forty-eight hours later, mice accumulate $30 \mathrm{sec}$ exploring a familiar and a novel object. More time than chance spent with the novel object indicates memory for the familiar object. OP is identical to NOR except that testing occurs $4 \mathrm{~h}$ after $\mathrm{E}_{2}$ infusion and one of the familiar objects is moved to a new location in the testing arena. More time with the moved object indicates memory for the unmoved object. Fourteen days elapsed between NOR and OP, and between OP and dorsal hippocampal tissue collection. (B) Mice infused with $\mathrm{E}_{2}$ spent significantly more time with the novel object than chance (dashed line at $15 \mathrm{sec}) 48 \mathrm{~h}$ after training $\left(\left[{ }^{* *}\right] P<0.01\right)$. (C) Mice infused with $\mathrm{E}_{2}$ also spent significantly more time with the moved object than chance (dashed line at $15 \mathrm{sec}) 4 \mathrm{~h}$ after training $([* * *] P<0.001)$. In contrast, mice treated with vehicle did not show a preference for either the novel $(B)$ or moved $(C)$ object, indicating that $\mathrm{E}_{2}$ enhanced both NOR and OP memory consolidation. Each bar represents the mean \pm SEM.

30-min time point by aging. $\mathrm{E}_{2}$ significantly increased acetyl $\mathrm{H} 3$ levels relative to vehicle $\left(F_{(2,23)}=10.91, P=0.0005\right)$ (Fig. $2 \mathrm{~A}$ ) both $30 \mathrm{~min}(P<0.0001)$ and $60 \mathrm{~min}(P<0.01)$ after infusion, suggesting that the $\mathrm{E}_{2}$-induced increase in $\mathrm{H} 3$ acetylation lasts at least $1 \mathrm{~h}$. In contrast to $\mathrm{H} 3, \mathrm{E}_{2}$ did not affect acetylation of $\mathrm{H} 2 \mathrm{~A}\left(F_{(2,17)}=0.2, P=0.83\right)($ Fig. $2 \mathrm{~B}), \mathrm{H} 2 \mathrm{~B}\left(F_{(2,24)}=0.8, P=0.46\right)$ (Fig. 2C), or H4 $\left(F_{(2,21)}=0.29, P=0.75\right)$ (Fig. 2D) at either 30 or $60 \mathrm{~min}$, suggesting that effects of $\mathrm{E}_{2}$ on histone acetylation are specific to $\mathrm{H} 3$.

\section{Estradiol decreases levels of histone deacetylases 2 and 3}

HDACs remove acetyl groups from histone tails, thereby condensing the chromatin and decreasing gene transcription. HDAC2 is a potent negative regulator of both hippocampal memory and synaptic plasticity (Guan et al. 2009). We previously showed that dorsal hippocampal infusion of $\mathrm{E}_{2}$ in young females significantly decreases HDAC2, but not HDAC1, protein in the dorsal hippocampus $4 \mathrm{~h}$ after infusion (Zhao et al. 2010, 2012). HDAC3 also negatively regulates object memory consolidation (McQuown et al. 2011), but the effects of $\mathrm{E}_{2}$ on HDAC3 levels in the hippocampus were unknown at any age. Therefore, we next used Western blotting to measure levels of HDAC1, HDAC2, and HDAC3 protein in the middle-aged dorsal hippocampus 4 and $6 \mathrm{~h}$ after bilateral dorsal hippocampal infusion of vehicle or 5- $\mu \mathrm{g} \mathrm{E}_{2}$. We hypothesized that $\mathrm{E}_{2}$ would decrease both HDAC2 and HDAC3 levels in middle-aged females because $\mathrm{E}_{2}$-induced memory enhancement is associated with decreased HDAC2 protein expression in young females (Zhao et al. 2010, 2012) and because $E_{2}$ enhances memory in middle-aged females (Fig. 1). As expected, $\mathrm{E}_{2}$ had no effect on HDAC1 protein levels at either time point $\left(F_{(2,22)}=\right.$ $0.61, P=0.6$ ) (Fig. 3A), but significantly decreased HDAC2
$\left(F_{(2,21)}=5.39, P=0.01\right) \quad($ Fig. 3B) and HDAC3 $\left(F_{(2,21)}=6.05, P=0.008\right)$ (Fig. $3 \mathrm{C})$ protein levels in the dorsal hippocampus. For HDAC2, this decrease was evident $4 \mathrm{~h}$ after infusion of $\mathrm{E}_{2}(P<$ $0.05)$, whereas HDAC3 levels were reduced both $4 \mathrm{~h}(P<0.01)$ and $6 \mathrm{~h}(P<$ $0.05)$ after infusion. These data suggest that $\mathrm{E}_{2}$ decreases levels of two key HDACs whose expression is associated with impaired memory.

\section{Estradiol increases BDNF protein and regulates acetylation of $B d n f$ promoters}

Traditionally, the estrogenic regulation of $B d n f$ has been attributed to classical genomic signaling mechanisms due to regulation of the $B d n f$ gene via an estrogen response element (ERE) (Sohrabji et al. 1995). However, as our lab and others have recently shown, $\mathrm{E}_{2}$ can activate rapid, nonclassical signaling pathways that may ultimately regulate gene transcription independent of the ERE (Bjornstrom and Sjoberg 2005; Spencer et al. 2008b; Fan et al. 2010). The Bdnf gene consists of eight $5^{\prime}$ untranslated exons and one $3^{\prime}$ exon (exon IX) that encodes the BDNF protein (Aid et al. 2007), with the ERE located on Exon $\mathrm{V}$ (Sohrabji et al. 1995). Transcription of each exon is driven by its own unique promoter (Aid et al. 2007). Of these promoters, pI, pII, pIV, and pVI are the most common in the brain (Baj et al. 2011). In the hippocampus, memory consolidation is associated with increased histone $\mathrm{H} 3$ acetylation at the pIV promoter (Lubin et al. 2008), and fear conditioning increases H3 acetylation at pI and pIV (Fuchikami et al. 2010). In contrast, aging is associated with a decrease in pII and pIV BDNF mRNA in the hippocampus of male rats (Perovic et al. 2013), but changes in acetylation have not been examined. Because $\mathrm{E}_{2}$ increases hippocampal BDNF mRNA (Singh et al. 1995; Sohrabji et al. 1995) and requires ERK-dependent $\mathrm{H} 3$ acetylation to enhance memory consolidation (Zhao et al. 2010), we hypothesized that $\mathrm{E}_{2}$ may increase acetylation of $\mathrm{H} 3$ at $B d n f$ promoters pI, pII, and pIV. Further, a role for $\mathrm{E}_{2}$ in regulating $\mathrm{H} 3$ acetylation of dorsal hippocampal $B d n f$ promoters has not been demonstrated at any age, so we used chromatin immunoprecipitation (ChIP) to examine effects in both young and middle-aged female mice.

Our control studies demonstrated specificity of the ChIP assay. We first confirmed, using Western blotting, that the panacetyl histone $\mathrm{H} 3$ was present in the nuclear fraction, but not the cytoplasmic fraction following our shearing protocol (Fig. 4B). Following immunoprecipitation, we observed a reduction in the signal for acetyl H3 in the supernatant samples immunoprecipitated with acetyl $\mathrm{H} 3$, suggesting antibody binding to beads coincubated with acetyl H3 rather than control IgG serum (Fig. $4 \mathrm{~B})$. Before testing our primers of interest, we used quantitative real-time PCR (qPCR) to ensure that our amplification was specific to the promoters of interest. We found no amplification in an IgG-only sample using primers for our negative control, LINE1 (LINE1). Following immunoprecipitation with acetyl H3, we observed a modest increase in the amplification of LINE1 (LINE1) and a threefold increase in the Nr4a2 positive control ( $\mathrm{Nr} 4 \mathrm{a} 2$ ) 
A
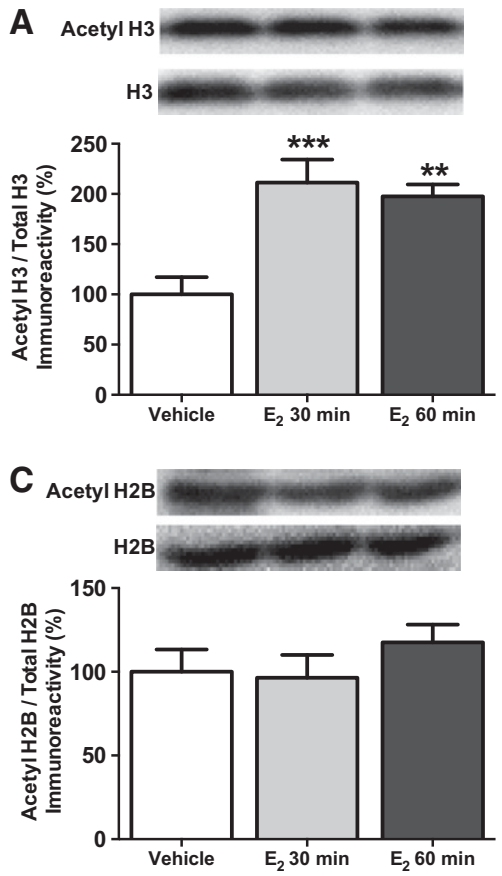

B
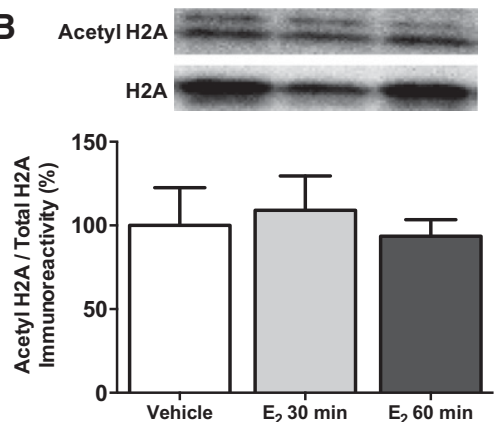

D

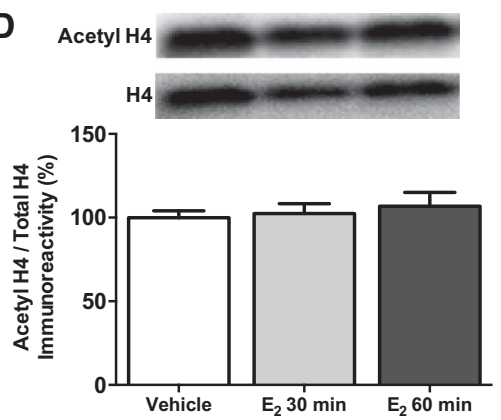

Figure 2. Dorsal hippocampal histone $\mathrm{H} 3$ acetylation is increased by $\mathrm{E}_{2}$. (A) Bilateral dorsal hippocampal infusion of $5-\mu \mathrm{g} \mathrm{E}_{2}$ significantly increased bulk acetyl $\mathrm{H} 3$ levels relative to vehicle 30 min $([* * *] P<0.001)$ and $60 \mathrm{~min}([* *] P<0.01)$ later. In contrast, $\mathrm{E}_{2}$ had no effect on the acetylation of histones $\mathrm{H} 2 \mathrm{~A}(B), \mathrm{H} 2 \mathrm{~B}(C)$, or $\mathrm{H} 4(D)$. All proteins were normalized to total histone (each bar represents the mean $[ \pm$ SEM] percent change from vehicle). (Insets) Representative Western blots of acetylated and total histone protein.

(Fig. 4C). The vehicle and $\mathrm{E}_{2}$ groups did not differ for any of the three targets.

Next, we compared the effects in young and middle-aged females of dorsal hippocampal vehicle or $\mathrm{E}_{2}$ infusion on $\mathrm{H} 3$ acetylation in promoters $\mathrm{pI}$, pII, and pIV. The main effects of age $\left(F_{(1,12)}=\right.$ $3.18, P=0.10)$ and $\mathrm{E}_{2}\left(F_{(1,12)}=2.68, P=0.13\right)$ were not significant for $\mathrm{H} 3$ acetylation at the pI promoter (Fig. 4A). Nevertheless, a $t$-test comparing young and middle-aged vehicle-infused mice did indicate a significant age-related decrease in $\mathrm{H} 3$ acetylation at $\mathrm{pI}\left(t_{(6)}=2.97, P=0.03\right)$. For the pII promoter, main effects of age $\left(F_{(1,12)}=15.26, P=0.03\right)$ and $E_{2}$ treatment $\left(F_{(1,12)}=15.26\right.$, $P=0.002$ ) were observed. As suggested by Figure $4 \mathrm{~A}, \mathrm{E}_{2}$ increased $\mathrm{H} 3$ acetylation of pII at both ages, but this effect was more pronounced for young females. $\mathrm{E}_{2}$ increased $\mathrm{H} 3$ acetylation at the pII promoter by $\sim 3.5$-fold $(P<0.01)$ in young females and $\sim 1.5$-fold in middle-aged females $\left(t_{(6)}=2.49, P=0.04\right.$ ) (Fig. 4A). There was also a trend for an age-related decrease in $\mathrm{H} 3$ acetylation of pII in vehicle-infused females $\left(t_{(6)}=2.1, P=0.08\right.$ ) (Fig. 4A). For the pIV promoter, the main effects of age $\left(F_{(1,19)}=8.36, P=0.009\right)$ and $\mathrm{E}_{2}\left(F_{(1,19)}=10.84, P=0.004\right)$ were also significant. Aging significantly decreased $\mathrm{H} 3$ acetylation at the pIV promoter $\left(t_{(10)}=\right.$ 4.76, $P=0.0008)$, and $\mathrm{E}_{2}$ significantly increased $\mathrm{H} 3$ acetylation in both young $(P<0.01)$ and middle-aged females $(P=0.05)$ by approximately onefold (Fig. 4A). These data demonstrate for the first time that $\mathrm{E}_{2}$ regulates histone acetylation of specific gene promoters in the dorsal hippocampus of adult females at any age, and suggest that $B d n f$ is a downstream gene target that may be necessary for the mnemonic effects of $\mathrm{E}_{2}$.

Next, to determine if dorsal hippocampal infusion of $\mathrm{E}_{2}$ influences BDNF protein levels, we measured both the uncleaved proform of BDNF, pro-BDNF, and mature BDNF. In middle-aged mice, bilateral dorsal hippocampal infusion of $\mathrm{E}_{2}$ significantly increased levels of pro-BDNF $\left(F_{(2,24)}=9.26, P=0.001\right)($ Fig. $5 \mathrm{~A})$ in the dorsal hippocampus both 4 and $6 \mathrm{~h}$ $(P<0.05)$ after infusion relative to vehicle. $E_{2}$ also significantly increased mature BDNF in the dorsal hippocampus of middle-aged mice $\left(F_{(2,21)}=3.96, \quad P=\right.$ $0.035)$ (Fig. 5B). As with pro-BDNF, this effect was evident both $4 \mathrm{~h}\left(t_{(15)}=2.35\right.$, $P=0.03)$ and $6 \mathrm{~h}(P<0.05)$ after infusion relative to vehicle. These data are the first to demonstrate that a direct infusion of $\mathrm{E}_{2}$ in the dorsal hippocampus can regulate pro-BDNF and mature BDNF protein levels in adult females of any age, and the time frame in which this happens suggests that nonclassical cell signaling mechanisms could underlie these changes.

\section{Discussion}

Because $\mathrm{E}_{2}$ is a potent regulator of hippocampal function, the age-related loss of $\mathrm{E}_{2}$ likely contributes to the increased risk of cognitive decline and dementia in postmenopausal women (Zandi et al. 2002; Yaffe et al. 2007). However, our previous and present work suggests that the dorsal hippocampus of the young and middle-aged female hippocampus is similarly responsive to $E_{2}$. For example, the present data replicate our previous report that post-training dorsal hippocampal infusion of $\mathrm{E}_{2}$ enhances NOR memory consolidation (Fan et al. 2010), and extends this finding to show that dorsal hippocampal $\mathrm{E}_{2}$ infusion also enhances spatial memory consolidation in middle-aged females. Our previous work also demonstrated that rapid ERK phosphorylation in the dorsal hippocampus is necessary for $\mathrm{E}_{2}$ to enhance NOR in both young and middle-aged mice (Fernandez et al. 2008; Fan et al. 2010), which suggests that the middle-aged female hippocampus remains at least partially responsive to $\mathrm{E}_{2}$. Because ERK-induced histone acetylation in the dorsal hippocampus is necessary for $\mathrm{E}_{2}$ to enhance NOR in young females (Zhao et al. 2010, 2012), we hypothesized that $\mathrm{E}_{2}$ would increase histone acetylation in the middle-aged dorsal hippocampus. Indeed, the pattern of $\mathrm{E}_{2^{-}}$ induced histone modifications was nearly identical in young and middle-aged females. As in young females (Zhao et al. 2012), $\mathrm{E}_{2}$ selectively increased dorsal hippocampal histone $\mathrm{H} 3$ acetylation 30 min after dorsal hippocampal infusion, and decreased dorsal hippocampal levels of HDAC2 (but not HDAC1) $4 \mathrm{~h}$ after infusion. This study also extends our previous work to show that $\mathrm{E}_{2}$ decreases levels of HDAC3 in the dorsal hippocampus both 4 and $6 \mathrm{~h}$ after infusion. Moreover, we show for the first time that $\mathrm{E}_{2}$ can regulate $\mathrm{H} 3$ acetylation of $B d n f$ promoters and levels of pro-BDNF and BDNF proteins in the dorsal hippocampus of both young and middleaged females. Together, this work provides the first evidence that the female middle-aged dorsal hippocampus remains epigenetically responsive to $\mathrm{E}_{2}$, and that $\mathrm{E}_{2}$ may enhance memory consolidation in middle-age females by increasing histone $\mathrm{H} 3$ acetylation of $B d n f$ promoters in the dorsal hippocampus.

Our data from middle-aged females showing that the consolidation of NOR and OP was enhanced $48 \mathrm{~h}$ and $4 \mathrm{~h}$ after dorsal hippocampal $\mathrm{E}_{2}$ infusion are consistent with our previous findings in young female mice (Boulware et al. 2013). These data are also consistent with reports that systemic $\mathrm{E}_{2}$ enhances NOR and OP memory $4 \mathrm{~h}$ after treatment in young female rats (Luine et al. 2003; Walf 

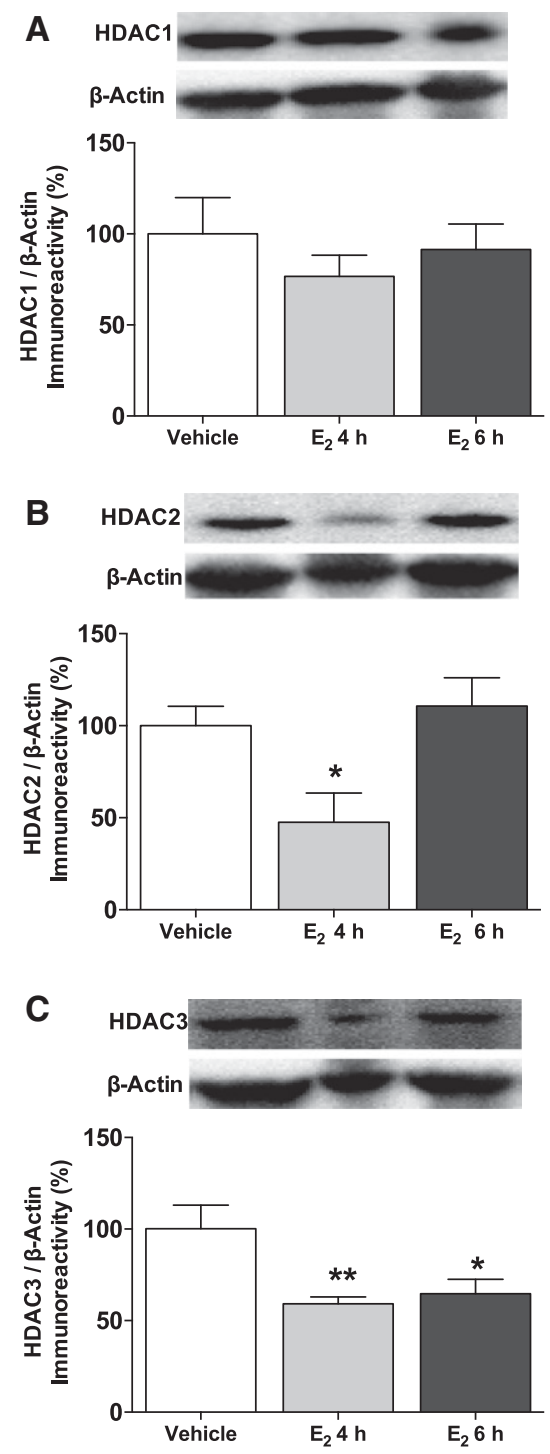

Figure 3. $E_{2}$ decreases levels of histone deacetylases. $(A)$ Bilateral dorsal hippocampal infusion of $5 \mu \mathrm{g}$ of $E_{2}$ did not alter HDAC1 protein levels in the dorsal hippocampus at either time point. $(B) E_{2}$ significantly decreased HDAC2 protein levels $4 \mathrm{~h}$ after infusion ([*] $P<0.05$ relative to vehicle). (C) $\mathrm{E}_{2}$ significantly decreased HDAC3 protein levels both $4 \mathrm{~h}\left(\left[{ }^{* *}\right] \mathrm{P}<\right.$ $0.01)$ and $\left.6 \mathrm{~h}\left({ }^{*}\right] P<0.05\right)$ later, relative to vehicle. All proteins were normalized to $\beta$-Actin (each bar represents the mean [ \pm SEM] percent change from vehicle). (Insets) Representative Western blots of total and phosphorylated protein.

et al. 2006; Frye et al. 2007). However, differences in the timing of spatial memory enhancement between young and middle-aged females should be noted. In young female mice, $\mathrm{E}_{2}$ and estrogen receptor agonists enhance OP $24 \mathrm{~h}$ after dorsal hippocampal infusion (Boulware et al. 2013), whereas the present study found that $\mathrm{E}_{2}$ does not enhance $\mathrm{OP}$ at this delay in middle-aged females. Rather, effects of $E_{2}$ on OP were seen here at the shorter 4-h postinfusion delay, suggesting that aging compromises the ability of $\mathrm{E}_{2}$ to enhance spatial memory. However, these data may reflect a detrimental effect of aging on spatial memory rather than a decreased responsiveness to $\mathrm{E}_{2}$, given reports that $\mathrm{OP}$ is more susceptible to aging than NOR (Wang et al. 2009; Wimmer et al. 2012). Despite potential age-related decline in spatial memory, memory consolidation in both NOR and OP was facilitated by dorsal hippo- campal infusion of $\mathrm{E}_{2}$, suggesting that the molecular mechanisms within the dorsal hippocampus that support object recognition and spatial memory consolidation remain responsive to $E_{2}$ in middle-aged females.

These mechanisms may include chromatin modifications, as suggested by the present data. As in young females (Zhao et al. 2010), $\mathrm{E}_{2}$ increased histone $\mathrm{H} 3$ acetylation in the dorsal hippocampus $30 \mathrm{~min}$ after infusion and decreased HDAC2 levels in the dorsal hippocampus $4 \mathrm{~h}$ after infusion. Not only were these effects present in middle-aged females, but they were also persistent, lasting at least $60 \mathrm{~min}$ for $\mathrm{H} 3$ acetylation and $6 \mathrm{~h}$ for HDAC3 levels. Such persistent changes may be evident in young females as well, but have not yet been examined. With respect to histone acetylation, the specificity of $\mathrm{E}_{2}$-induced changes to $\mathrm{H} 3$ is consistent with our previous work in young females (Zhao et al. 2010, 2012) and with contextual fear-induced changes in the hippocampus of male rats (Levenson et al. 2004; Chwang et al. 2006). With respect to HDAC levels, the failure of $\mathrm{E}_{2}$ to regulate HDAC1 levels is consistent with our previous data from young female mice (Zhao et al. 2010, 2012). These data also support evidence that hippocampal HDAC1 is necessary for the extinction of fear memory, but not for NOR memory (Bahari-Javan et al. 2012). In contrast, the $\mathrm{E}_{2}$-induced reduction of dorsal hippocampal HDAC2 and HDAC3 levels corresponds with other studies showing that these HDACs negatively regulate hippocampal memory (Guan et al. 2009; McQuown et al. 2011). Notably, Hdac2 knockout mice display enhanced acetylation of genes that regulate synaptic plasticity and memory (Guan et al. 2009) and shRNA knockdown of Hdac2 restores memory deficits in a mouse model of Alzheimer's disease (Graff et al. 2012). Similarly, specific deletion of Hdac3 in the dorsal hippocampus enhances long-term NOR memory (McQuown et al. 2011). Here, we provide the first evidence that $\mathrm{E}_{2}$ reduces HDAC3 protein in the dorsal hippocampus, thus supporting HDAC2 and HDAC3 as negative regulators of memory.

Findings showing that $\mathrm{E}_{2}$ administered 2 or $3 \mathrm{~h}$ after training does not enhance spatial memory or object recognition (Packard and Teather 1997a,b; Fernandez et al. 2008) support the temporal specificity of $\mathrm{E}_{2}$ 's effects on the memory consolidation phase of memory formation. Therefore, $\mathrm{E}_{2}$-induced changes in cell signaling and epigenetic modifications likely follow a specific time course in order to facilitate memory consolidation. Acute systemic injections of $\mathrm{E}_{2}$ in young female rats can increase spine density in the hippocampus within $30 \mathrm{~min}$ (Inagaki et al. 2012), an effect that is ERK-dependent in vitro (Srivastava et al. 2008). Our laboratory has shown in young female mice that $\mathrm{E}_{2}$ increases the phosphorylation of p42 ERK and activates ERK-driven mammalian target of rapamycin (mTOR) protein synthesis pathway 5 min after dorsal hippocampal infusion (Fernandez et al. 2008; Boulware et al. 2013; Fortress et al. 2013b), which suggests a possible increase in synaptogenesis as early as $5 \mathrm{~min}$ after infusion. We also found in young females that $\mathrm{E}_{2}$ increases dorsal hippocampal HAT activity 30 min after infusion, and that ERK activation is necessary for the $\mathrm{E}_{2}$-induced acetylation of H3 30 min after infusion (Zhao et al. 2010). In young ovariectomized female mice, histone acetylation must be increased within $3 \mathrm{~h}$ of NOR training to facilitate memory consolidation (Zhao et al. 2010), and is essential for the reduction in $\mathrm{E}_{2}$-induced HDAC2 observed $4 \mathrm{~h}$ after infusion (Zhao et al. 2010, 2012). Therefore, the data suggest that $\mathrm{E}_{2}$-induced alterations in histone acetylation occur within the time frame of memory consolidation, and lead to subsequent alterations in levels of HDAC2 protein. This evidence leads us to hypothesize that $\mathrm{E}_{2}$-induced changes in $\mathrm{H} 3$ acetylation are responsible for the initial consolidation of the memory, and that a subsequent decrease in HDAC2 expression may be involved in the maintenance of the memory. Support for this notion comes from evidence that HDAC inhibitors increase the persistence of object recognition memories for up to a 

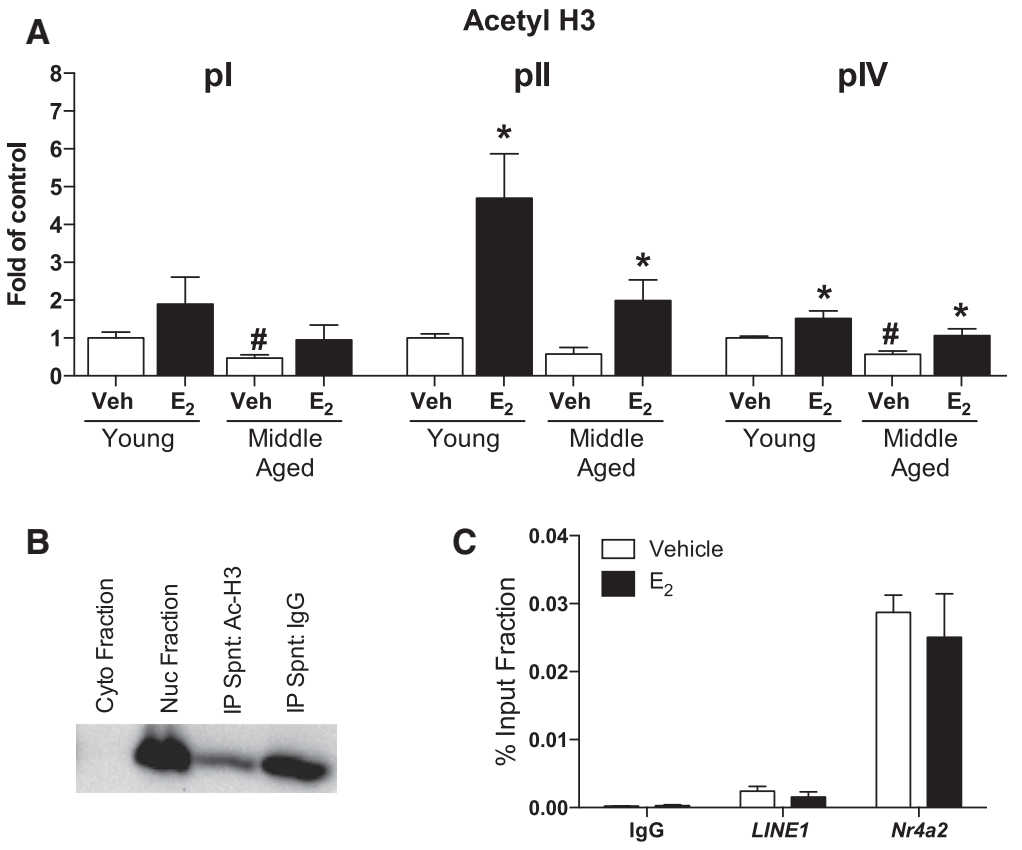

Figure 4. $\mathrm{E}_{2}$ increases histone $\mathrm{H} 3$ acetylation of $B d n f$ promoters in the dorsal hippocampus. $(A)$ Chromatin immunoprecipitation analysis of histone $\mathrm{H} 3$ acetylation at the $B d n f$ pl, pll, and pIV promoter regions. Age-related decreases in acetylation were evident among vehicle-infused females at the $\mathrm{pl}$ and pIV promoters ( $\left[{ }^{\#}\right] P<0.05$ compared to young vehicle-infused mice). $\mathrm{E}_{2}$ increased $\mathrm{H} 3$ acetylation at the pll and pIV promoters 30 -min post-infusion in both young and middle-aged mice $\left({ }^{*}\right] P<0.05$ vs. age-matched control). Data were normalized to LINE1 for each sample and then normalized to young vehicle-infused mice for each promoter region and represented as fold of control. Each bar represents the mean \pm SEM. (B) Western blot demonstrating specificity of sonication parameters. Pan-acetyl histone $\mathrm{H} 3$ was not evident in the cytoplasmic fraction (lane 1), but was present in the nuclear fraction (lane 2). The presence of $\mathrm{H} 3$ acetylation (Ac-H3) was reduced in the IP supernatant removed from the incubation containing the beads and the acetyl- $\mathrm{H} 3$ antibody (lane 3), but remained fully present in the IP supernatant with beads not containing acetyl-H3 antibody (lane 4). (C) qPCR data showing the absence of nonspecific binding in the IgG only control when amplified using primers for LINE1 (LINE1), no difference in the expression of the LINE1 negative control (LINE1), and a threefold increase in expression of the $\mathrm{Nr} 4 a 2$ positive control ( $\mathrm{Nr} 4 a 2)$ in vehicle- and $\mathrm{E}_{2}$-infused mice.

week longer than normally observed (Stefanko et al. 2009; Zhao et al. 2010).

Despite our previous findings showing that $\mathrm{E}_{2}$ regulates histone acetylation in the dorsal hippocampus of young females, the identity of the epigenetically regulated genes has remained unknown. Although there are likely numerous gene targets, $B d n f$ is a logical candidate given the well-documented relationship between $\mathrm{E}_{2}$ and $\mathrm{BDNF}$ (for recent reviews, see Harte-Hargrove et al. 2013; Luine and Frankfurt 2013; Pluchino et al. 2013). $E_{2}$ increases BDNF mRNA and protein, BDNF release, and activation of TrkB in the hippocampus (Sohrabji et al. 1995; Zhou et al. 1996; Scharfman et al. 2003; Sato et al. 2007; Aguirre and Baudry 2009). This regulation of BDNF by $\mathrm{E}_{2}$ is significant because cellular processes necessary for hippocampal function, like dendritic spinogenesis and long-term potentiation (LTP), are dependent on BDNF and its high affinity receptor, TrkB (Luine and Frankfurt 2013). Collectively, this literature led us to hypothesize that $\mathrm{E}_{2}$ would increase histone $\mathrm{H} 3$ acetylation at $B d n f$ promoters. We focused on the $B d n f$ pI, pII, and pIV promoters because $\mathrm{H} 3$ acetylation of these promoters is closely associated with hippocampal learning and aging (Lubin et al. 2008; Fuchikami et al. 2010; Perovic et al. 2013). We found that aging significantly decreased $\mathrm{H} 3$ acetylation of $\mathrm{pI}$ and pIV, and tended to decrease acetylation of pII. These findings are generally consistent with data from male rats showing significant age-related reductions in $B d n f$ pII and pIV (Perovic et al. 2013). Despite these reductions, we found that $E_{2}$ significantly in- creased $\mathrm{H} 3$ acetylation of pII and pIV, but had no effect on pI. The specific roles of each $B d n f$ mRNA transcript in hippocampal function are still unclear. $B d n f$ pI is located largely in the soma of CA1 pyramidal neurons, whereas pII and pIV are located primarily in proximal and distal dendrites, respectively (Baj et al. 2011). Interestingly, pIV is regulated by calcium through L-type calcium channels (Zheng et al. 2011). $\mathrm{E}_{2}$ activates the L-type calcium channels necessary for ERK signaling (Wu et al. 2005; Sarkar et al. 2008), and we have shown that ERK signaling is required for H3 acetylation (Zhao et al. 2010). Activation of L-type calcium channels by ERK promotes CREB phosphorylation (Wu et al. 2005), which can facilitate epigenetic changes by increasing CBP occupancy at gene promoters important for synaptic plasticity (Bousiges et al. 2010). In fact, a synthetic CBP analog has recently been shown to increase acetylation of $B d n f$ pI in addition to increasing BDNF mRNA and protein levels (Chatterjee et al. 2013). As such, $E_{2}$ may increase $H 3$ acetylation at pIV by activating L-type calcium channels, thereby phosphorylating ERK, and increasing the expression of $B d n f$ mRNA at distal dendrites. These changes could increase the pool of resident mRNA for local BDNF synthesis to facilitate synaptic plasticity, but this speculation has yet to be tested. It will also be of interest in future studies to determine how $E_{2}$ regulates expression of other $B d n f$ transcripts and the extent to which $\mathrm{E}_{2}$ increases $\mathrm{H} 3$ acetylation of promoters for other synaptic plasticity genes like Egr1 and c-fos, the latter of which is transcribed within $15 \mathrm{~min}$ after dorsal hippocampal $\mathrm{E}_{2}$ infusion in young female mice (Zhao et al. 2010).

$\mathrm{E}_{2}$ also increased pro-BDNF and BDNF protein levels in middle-aged females 4 and $6 \mathrm{~h}$ after dorsal hippocampal infusion. Combined with our ChIP data, these results suggest that $\mathrm{E}_{2}$ induces a transcriptionally permissive state at the $B d n f$ promoter within 30 min, which may increase levels of $B d n f$ transcripts and BDNF protein within $4 \mathrm{~h}$. Evidence that BDNF is transcribed within 30-60 min and translated within $4-6 \mathrm{~h}$ is supported by other studies demonstrating that visual experience affects BDNF synthesis in visual cortex (Schwartz et al. 2011) and that vibrissae stimulation affects BDNF synthesis in somatosensory cortex and hippocampus (Nanda and Mack 2000). Although protein changes in the order of hours could suggest regulation of the BDNF gene by classic genomic signaling through nuclear estrogen receptors at the BDNF ERE (Sohrabji et al. 1995), the present data instead implicate rapid nonclassical epigenetic regulation of BDNF. Other rapid regulation of BDNF by $E_{2}$ has been observed; for example, $E_{2}$ facilitates hippocampal synaptogenesis by increasing BDNF release through a rapid PKA-dependent mechanism (Sato et al. 2007). Interestingly, exogenous BDNF increases expression of $B d n f$ pIV mRNA within $1 \mathrm{~h}$ of application (Zheng et al. 2012). These data suggest a feedback mechanism in which BDNF levels regulate BDNF signaling. Such a mechanism is supported by in vitro evidence that BDNF increases BDNF protein by nitrosylating cysteine residues on HDAC2 (Nott 
A
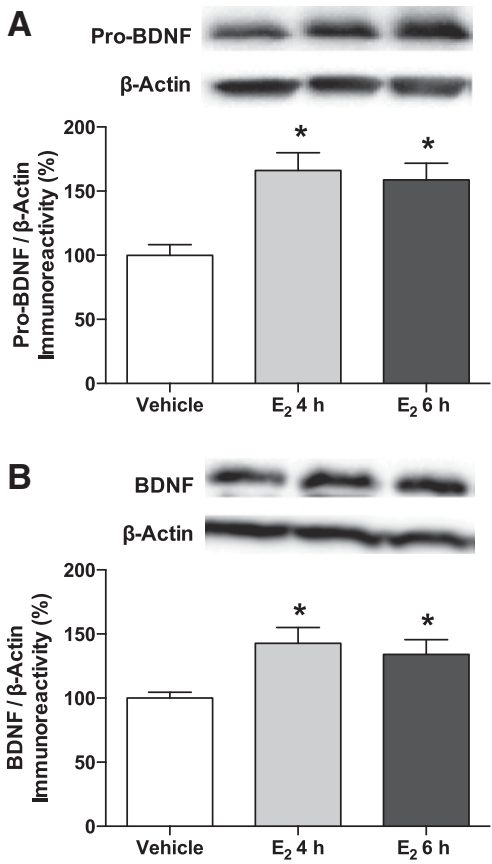

Figure 5. Pro-BDNF and $B D N F$ proteins were increased by $E_{2}$. $(A)$ Bilateral dorsal hippocampal infusion of $5 \mu \mathrm{g}$ of $E_{2}$ significantly increased pro-BDNF protein levels relative to vehicle $4 \mathrm{~h}\left(\left[^{*}\right] P<0.05\right)$ and $6 \mathrm{~h}\left(\left[^{*}\right]\right.$ $P<0.05)$ after infusion. $(B)$ Similarly, BDNF protein was increased relative to vehicle $4 \mathrm{~h}\left(\left[^{*}\right] P<0.05\right)$ and $6 \mathrm{~h}\left(\left[^{*}\right] P<0.05\right)$ after $E_{2}$ infusion. All proteins were normalized to $\beta$-Actin (each bar represents the mean [ \pm SEM] percent change from vehicle). (Insets) Representative Western blots showing total and phosphorylated protein levels.

et al. 2008; Graff and Tsai 2013a). Thus, one way in which $\mathrm{E}_{2}$ may facilitate memory consolidation in middle-aged females is by priming this BDNF positive feedback loop. Indeed, $\mathrm{E}_{2}$ levels are positively correlated with the expression of activated TrkB receptors (Spencer et al. 2008a). However, the potential interactions between $\mathrm{E}_{2}$ and the BDNF feedback loop will need to be examined in future studies. It should be noted, however, that our studies cannot definitively exclude other mechanisms regulating pro-BDNF and BDNF protein levels. It is unclear whether ER $\alpha$ and ER $\beta$ are involved in estrogenic regulation of histone acetylation, but both receptors are present in neurons within the hippocampus. Both ER $\alpha$ and ER $\beta$ have been localized to nuclei, axons, and dendritic spine synapses of CA1 pyramidal neurons in the hippocampus (Milner et al. 2001, 2005), and $E R \alpha$ is present in GABAergic interneurons (Murphy et al. 1998b) and cholinergic axons and terminals (Towart et al. 2003) within the hippocampus. In 2- to 3-wk-old hippocampal cell cultures, $\mathrm{E}_{2}$ down-regulates BDNF immunoreactivity in GABAergic interneurons, which reduces inhibition and increases excitatory tone and dendritic spine density in pyramidal neurons (Murphy et al. 1998a). Similarly, other data suggest that estrogenic stimulation of the basal forebrain cholinergic system disinhibits hippocampal pyramidal neuron by reducing GABAergic neurotransmission (Rudick et al. 2003). These data suggest complex interactions between $\mathrm{E}_{2}$ and $\mathrm{BDNF}$ involving multiple neuron types within the hippocampus. As such, future studies should specifically examine epigenetic regulation of BDNF in glutamatergic, GABAergic, and cholinergic cell types to gain a better understanding of how $\mathrm{E}_{2}$ regulates BDNF and pro-BDNF proteins.

In conclusion, our findings provide the first evidence that the middle-aged female dorsal hippocampus remains epigenetically responsive to $E_{2}$, and suggest that $E_{2}$ may enhance memory in middle-aged females via epigenetic regulation of $B d n f$. Because women are at greater risk than men for developing Alzheimer's disease (Yaffe et al. 2007) and mental illnesses such as depression, anxiety, and mood disorders (Kessler et al. 2005), these findings may provide key insight into the hormonal regulation of cognition in women. Understanding how $\mathrm{E}_{2}$ epigenetically regulates $B d n f$ in females throughout the lifespan will provide essential new information for the development of more effective treatments for women with neurodegenerative and neuropsychiatric illnesses.

\section{Materials and Methods}

\section{Subjects}

Middle-aged (16-mo-old) female C57BL/6 mice were obtained from the National Institutes on Aging Aged Rodent Colony at Charles River Laboratories. For chromatin immunoprecipitation studies, young (3-mo-old) female C57BL/6 mice were obtained from Taconic. All mice were singly housed and maintained on a 12-h light-dark cycle (lights on at 07:00) with ad libitum access to food and water. All procedures followed the National Institutes of Health Guide for the Care and Use of Laboratory Animals and were approved by the University of Wisconsin-Milwaukee Institutional Animal Care and Use Committee.

\section{Surgery}

All mice were bilaterally ovariectomized and implanted with guide cannulae within the same surgical session as described previously (Fortress et al. 2013b). Using a stereotaxic apparatus, bilateral stainless-steel guide cannulae (22-gauge, C232G, Plastics One) were implanted into the dorsal hippocampus $(-1.7 \mathrm{~mm}$ $\mathrm{AP}, \pm 1.5 \mathrm{~mm} \mathrm{ML},-2.3 \mathrm{~mm} \mathrm{DV}$ [injection site]) and were fitted with dummy cannulae (C232DC) to preserve the integrity of the guide cannulae. Dental cement (Darby Dental) was used to affix the cannulae to the skull surface and also served to close the wound. Mice were allowed to recover for $7 \mathrm{~d}$ before the start of behavioral training.

\section{Drugs and infusions}

All mice were infused with vehicle or $\mathrm{E}_{2}$. Cyclodextrin-encapsulated $\mathrm{E}_{2}$ (Sigma-Aldrich) was dissolved to a concentration of 5 $\mu \mathrm{g} / 0.5 \mu \mathrm{L}$ in physiological saline as described previously (Fortress et al. 2013b). The vehicle, 2-hydroxypropyl- $\beta$-cyclodextrin (HBC, Sigma-Aldrich), was dissolved in saline to the same concentration of cyclodextrin used in the cyclodextrin- $\mathrm{E}_{2}$ solution. During infusions, mice were gently restrained and dummy cannulae were replaced with infusion cannulae (C232I, 26 gauge extending 0.8 $\mathrm{mm}$ beyond the $1.5-\mathrm{mm}$ guide cannulae), which were attached to PE50 tubing connected to a $5-\mu \mathrm{L}$ Hamilton syringe. Using a microinfusion pump (KDS 100, KD Scientific), mice were bilaterally infused into the dorsal hippocampus at a rate of $0.5 \mu \mathrm{L} / \mathrm{min}$ for $1 \mathrm{~min}$, resulting in an $\mathrm{E}_{2}$ dose of $5 \mu \mathrm{g} /$ hemisphere. Infusion cannulae remained in place for $1 \mathrm{~min}$ to prevent diffusion back up the cannula track. Infusions occurred immediately after behavioral training (i.e., post-training). Infusions were spaced out by $2 \mathrm{wk}$ to allow the acute effects of $\mathrm{E}_{2}$ to dissipate, and all mice received the same number of infusions.

\section{Behavioral testing}

To examine the effects of $\mathrm{E}_{2}$ on object recognition and spatial memory, mice $(n=79)$ were tested in both novel object recognition (NOR) and object placement (OP) (Fig. 1A) tasks. NOR was first used to assess nonspatial hippocampal-dependent memory as described previously (Fortress et al. 2013b). Mice were handled for 30 $\mathrm{sec} / \mathrm{d}$ for $3 \mathrm{~d}$ prior to habituation. A small Lego was placed in the home cage from the start of handling until training to habituate the mice to the objects. Mice were habituated to the testing arena for $2 \mathrm{~d}$, during which time they were allowed to freely explore the empty, white testing arena $(60-\mathrm{cm} \mathrm{W} \times 60-\mathrm{cm} \mathrm{L} \times 47-\mathrm{cm} \mathrm{H})$ for 5 min. Twenty-four hours after the second habituation session, mice 
were rehabituated to the testing arena for $2 \mathrm{~min}$, and then placed in a holding cage while two identical objects were placed in the Northeast and Northwest corners of the box $(\sim 5 \mathrm{~cm}$ from the walls). Mice were then immediately returned to the testing arena and allowed to freely explore both objects until they accumulated a total of $30 \mathrm{sec}$ of exploration time, with a maximum of 20 min allowed for completion of training. Exploration was recorded when the front paws or nose contacted either object. Immediately after training, mice were removed from the box, gently restrained, and were bilaterally infused with vehicle or $\mathrm{E}_{2}$ into the dorsal hippocampus. Forty-eight hours after infusion, mice were returned to the testing arena and allowed to accumulate $30 \mathrm{sec}$ exploring an object identical to that explored during training (familiar) and a new (novel) object. Novel object location was counterbalanced across mice. Time spent exploring each object was recorded using ANYmaze software (Stoelting). More time than chance (15 sec) spent exploring the novel object indicated memory for the familiar object.

Two weeks after the completion of NOR, spatial memory was tested using an OP protocol as described previously (Boulware et al. 2013). Mice were rehabituated to the testing arena for 2 min and were then allowed to explore two identical objects placed in the Northeast and Northwest corners as in NOR. Immediately after training, mice were infused with vehicle or $\mathrm{E}_{2}$ as above. Either 4 or $24 \mathrm{~h}$ after training, mice were returned to the testing arena in which one of the identical objects had been moved to the Southeast or Southwest corner. The location of the moved object was counterbalanced across mice. Mice were again allowed to accumulate $30 \mathrm{sec}$ with the objects. More time than chance (15 sec) spent exploring the moved object indicated memory for the unmoved object.

\section{Western blotting}

Two weeks after the completion of OP, mice were again infused with vehicle $(n=16)$ or $\mathrm{E}_{2}(n=36)$ into the dorsal hippocampus, and dorsal hippocampal tissues were collected bilaterally on ice 30 min, $60 \mathrm{~min}, 4 \mathrm{~h}$, or $6 \mathrm{~h}$ later for measurement of histone acetylation (H2A, H2B, H3, and H4), and levels of HDAC1, HDAC2, and HDAC3 protein. Our previous studies in young females showed that dorsal hippocampal infusion of $\mathrm{E}_{2}$ increased $\mathrm{H} 3$ acetylation $30 \mathrm{~min}$ later and decreased HDAC2 protein $4 \mathrm{~h}$ later (Zhao et al. 2010,2012 ). However, because we also found that activation of ERK is delayed in middle-aged females relative to young females (Fan et al. 2010), and that ERK activation is necessary for $E_{2}$ to increase H3 acetylation (Zhao et al. 2010), we included the 60-min and 6-h time points here to account for potential age-related delays in histone modifications. Dorsal hippocampal tissues were maintained at $-80^{\circ} \mathrm{C}$ until homogenization.

Tissues were prepared as described previously (Fortress et al. 2013a), with the exception of those used for histone extraction. For tissue collected at 30 and $60 \mathrm{~min}$ to measure histone acetylation, tissues were dounce homogenized with a Teflon homogenizer after resuspension in 1:50 w/v of $1 \times$ Laemelli buffer diluted from $5 \times$ Laemelli buffer (50\% glycerol in water containing 587 $\mathrm{mM}$ Tris $\mathrm{HCl}, 38 \mathrm{mM}$ Tris Base, $173 \mathrm{mM}$ SDS) containing 100 mM PMSF, and $1 \times$ Protease Inhibitor Cocktail. Homogenates were then incubated in a $37^{\circ} \mathrm{C}$ water bath for $10 \mathrm{~min}$ and centrifuged at $12,000 \mathrm{rpm}$ for $5 \mathrm{~min}$ at $4^{\circ} \mathrm{C}$. For all other proteins to be assayed at the 4- and 6-h time points, tissues were homogenized in $1: 25 \mathrm{w} / \mathrm{v}$ dilution in lysis buffer and homogenized with a probe sonicator (Branson Sonifier 250). After total protein content was measured for all samples (Fernandez et al. 2008), $20 \mu \mathrm{g}$ of sample was electrophoresed on various gradients of Tris-HCl gels and transferred to PVDF membranes using the TransBlot Turbo system (Bio-Rad). Membranes were blocked and incubated with the following anti-rabbit primary antibodies overnight at $4^{\circ} \mathrm{C}$ : acetyl-H2A (Lys 5), acetyl-H2B (Lys 12) (1:1000, Cell Signaling Technology), acetyl-H3 (pan), acetyl-H4 (Lys 12), HDAC1, HDAC2, or HDAC3 (1:1000, Cell Signaling Technology). The next day, membranes were washed and incubated in secondary antibody (anti-rabbit HRP, 1:5000, Cell Signaling Technology), and then developed in West Dura Chemiluminescent substrate
(Pierce). For normalization of histone proteins, blots were stripped and reprobed with anti-rabbit antibodies for corresponding total histone proteins H2A, H2B (1:1000, Cell Signaling Technology), H3, or H4 (1:2000, Millipore). Anti- $\beta$-Actin (1:5000, Cell Signaling Technology) was used to normalize all other proteins. Images were captured and densitometry was performed using the Carestream Gel Logic 6000 Pro. All normalized proteins were expressed as a percentage relative to vehicle controls.

\section{Chromatin immunoprecipitation (ChIP)}

ChIP was performed using a previously published protocol (Kenney et al. 2012). Thirty minutes after infusion with vehicle or $\mathrm{E}_{2}$, young $(n=15)$ and middle-aged mice $(n=13)$ were cervically dislocated, and the dorsal hippocampus was rapidly dissected, flash frozen, and stored at $-80^{\circ} \mathrm{C}$ until use. Tissues were minced and proteins cross-linked by placing them for $10 \mathrm{~min}$ in $1 \%$ formaldehyde on a rotator at room temperature. Glycine (200 $\mathrm{mM}$ ) was then added for $5 \mathrm{~min}$ to stop the cross-linking reaction, and the tissue was then centrifuged at $2500 \mathrm{rpm}$ for $2 \mathrm{~min}$ at $4^{\circ} \mathrm{C}$. The supernatant was removed and the samples were washed three times with ice-cold phosphate buffered saline (PBS) containing protease and phosphatase inhibitors (PPI) (Pierce), with centrifugation at $2500 \mathrm{rpm}$ for $2 \mathrm{~min}$ at $4^{\circ} \mathrm{C}$ between each wash. To lyse the cells, tissue was homogenized on ice in $500 \mu \mathrm{L}$ of lysis buffer (1× PPI, $10 \mathrm{mM}$ Tris-HCl [pH 8.1], $10 \mathrm{mM} \mathrm{NaCl}, 1.5 \mathrm{mM} \mathrm{MgCl}$, $0.5 \%$ Igepal-CA630) using a sterile pestle homogenizer, then centrifuged at $5500 \mathrm{rpm}$ for $5 \mathrm{~min}$ at $4^{\circ} \mathrm{C}$. The supernatant was then removed and $150 \mu \mathrm{L}$ of nuclear lysis buffer $(1 \times$ PPI, $50 \mathrm{mM}$ Tris- $\mathrm{HCl}$ [pH 8.1], 5 mM EDTA, 1\% SDS) was added. For chromatin shearing, samples were incubated on ice for $10 \mathrm{~min}$ and then sonicated on ice using a probe sonicator (10 cycles of 15 -sec on, 120 -sec off at $25 \%$ power) (Branson Sonifier 250). These conditions yielded chromatin fragments in the $100-800$ base pair range. Following sonication, $5 \mu \mathrm{L}$ of sample was eluted in ChIP elution buffer $\left(1 \%\right.$ SDS, $\left.0.1 \mathrm{M} \mathrm{NaHCO}_{3}\right)$ and $0.1 \mu \mathrm{g} / \mu \mathrm{L}$ proteinase $\mathrm{K}$ (Invitrogen), and then incubated for $2 \mathrm{~h}$ at $62^{\circ} \mathrm{C}$ on a rotator. Cross-links were then reversed by incubation at $95^{\circ} \mathrm{C}$ for $10 \mathrm{~min}$. Resulting DNA was purified using QiaQuick spin columns (Qiagen). The following day, purified DNA fragments were used to check DNA concentration and efficiency of chromatin shearing. To detect the size of base pair fragments, samples were electrophoresed in 1.5\% agarose in TAE buffer containing Sybr Safe and visualized using UV luminescence on the ChemiDoc MP Gel Imaging System (Bio-Rad). All fragments of DNA were determined to be in the 100-800 base pair range. For the immunoprecipitation (IP) process, $2 \mu \mathrm{g}$ of DNA was mixed with IP buffer $(16.7 \mathrm{mM}$ Tris-HCl [pH 8.1], 1.1\% Triton X-100, 0.01\% SDS, $167 \mathrm{mM} \mathrm{NaCl}$ ) with $1 \times$ PPI to a volume of $500 \mu \mathrm{L}$. Five microliters of the IP mix was removed as $1 \%$ input prior to the addition of beads and antibody. This process resulted in three tubes for each sample: input, acetyl-H3, or IgG control. For tubes receiving acetyl-H3, $5 \mu \mathrm{L}$ of pan-acetyl H3 antibody (Millipore \#06-599) was added. For IgG control tubes, $1 \mu \mathrm{L}$ of rabbit IgG (Cell Signaling Technology) was added. Twenty microliters of protein A magnetic beads (Millipore) were then added to the acetyl-H3 and IgG tubes, and incubated overnight on a rotator at $4^{\circ} \mathrm{C}$. Following incubation, the acetyl-H3 and IgG tubes were washed once each with low salt (20 $\mathrm{mM}$ Tris $\mathrm{HCl}, 150 \mathrm{mM} \mathrm{NaCl}, 2 \mathrm{mM}$ EDTA, 1\% Triton-X, $0.1 \%$ SDS), high salt (20 mM Tris $\mathrm{HCl}, 500 \mathrm{mM} \mathrm{NaCl}, 2 \mathrm{mM}$ EDTA, $1 \%$ Triton-X, 0.1\% SDS), LiCl (10 mM Tris HCl, $250 \mathrm{mM} \mathrm{LiCl}, 1 \mathrm{mM}$ EDTA, 1\% deoxycholate, 1\% Igepal-CA630), and TE (10 mM Tris $\mathrm{HCl}, 1 \mathrm{mM}$ EDTA) wash buffers. All tubes were then incubated in elution buffer $\left(0.1 \mathrm{M} \mathrm{NaHCO}_{3}, 1 \% \mathrm{SDS}\right)$ and $0.1 \mu \mathrm{g} / \mu \mathrm{L}$ proteinase $\mathrm{K}$ (Invitrogen) for $2 \mathrm{~h}$ at $62^{\circ} \mathrm{C}$. Cross-links were reversed via incubation at $95^{\circ} \mathrm{C}$ for $10 \mathrm{~min}$. DNA was isolated and purified using QiaQuick spin columns (Qiagen) and eluted twice in nuclease-free water to a total volume of $200 \mu \mathrm{L}$.

\section{Quantitative real-time PCR ( $\mathrm{qPCR}$ )}

For each qPCR reaction, $9 \mu \mathrm{L}$ of DNA was combined with $250 \mathrm{nM}$ primer solution and $10 \mu \mathrm{L}$ of EVAGreen SYBR Green Master Mix 
(Midwest Scientific) for a final volume of $20 \mu \mathrm{L}$. Each sample (input, acetyl-H3, and IgG) was loaded in triplicate using the Eppendorf Realplex 2 PCR System (Eppendorf). Cycle conditions were determined by EVAGreen guidelines: $95^{\circ} \mathrm{C}$ for $10 \mathrm{~min}, 40 \mathrm{cy}$ cles of $95^{\circ} \mathrm{C}$ for $20 \mathrm{sec}, 40$ cycles of $95^{\circ} \mathrm{C}$ for $15 \mathrm{sec}$, and $60^{\circ} \mathrm{C}$ for $60 \mathrm{sec}$. At the completion of the qPCR reactions, melt curves and product size analyses were performed for each primer. Additionally, using mouse genomic DNA, the efficiency of each of the primers was calculated and determined to be at $100 \pm 10 \%$ before analyzing the results. The following primer sequences were used:

Bdnf pI forward 5'-TGATCATCACTCACGACCACG-3', pI reverse 5'-CAGCCTCTCTGAGCCAGTTACG-3' (Graff et al. 2012); Bdnf pII forward 5'-CCGTCTTGTATTCCATCCTTTG-3', pII reverse 5'-CCCAACTCCACCACTATCCTC-3' (Graff et al. 2012); $B d n f$ pIV forward 5'-GCGCGGAATTCTGATTCTGGTAAT-3', reverse 5'-GAGAGGGCTCCACGCTGCCTTGACG-3' (Zeng et al. 2011);

LINE1 forward 5'-AAACGAGGAGTTGGTTCTTTGAG-3', reverse 5'-TTTGTCCCTGTGCCCTTTAGTGA-3' (Kenney et al. 2012);

nr4a2 forward 5'-GTGTGAGGACGCAAGGTCTG-3', reverse 5'-CACGACTGGGGCTGATTT-3' (Kenney et al. 2012).

\section{Statistical analyses}

For NOR and OP, independent sample $t$-tests were used to determine if the time each group spent with the novel or moved objects differed significantly from chance (15 sec) (Boulware et al. 2013; Fortress et al. 2013a). This test was used because time spent with the objects is not independent; time spent with one necessarily reduces time spent with the other (Frick and Gresack 2003). Western blot data were analyzed using a one-way analysis of variance with Dunnett's planned comparisons for post hoc analyses (Fortress et al. 2013b). For qPCR analyses, median Ct values were used with the $\Delta \Delta$ Ct method then normalized to young, vehicle mice (Zhao et al. 2010). ChIP data are presented as fold change over young vehicle infused mice. A $2 \times 2$ analysis of variance, with age and treatment as independent variables and selected planned $t$-tests were used to determine statistical differences for each of the promoter regions. All data were analyzed using GraphPad Prism 6 (GraphPad Software, Inc.) and significance for all analyses was determined as $P \leq 0.05$.

\section{Acknowledgments}

This project was supported by the University of WisconsinMilwaukee, a Research Growth Initiative grant from the UWM Research Foundation to K.M.F; an Ellison Medical Foundation/ American Federation for Aging Research Postdoctoral Fellowship in Aging to A.M.F.; and a National Institute on Drug Abuse (NIDA) grant, DA017949, to T.J.G. We thank Dr. Ava Udvadia for helpful advice on the ChIP analyses and the Great Lakes Genomic Center for the use of its NanoDrop spectrophotometer.

\section{References}

Aguirre CC, Baudry M. 2009. Progesterone reverses $17 \beta$-estradiol-mediated neuroprotection and BDNF induction in cultured hippocampal slices. Eur J Neurosci 29: 447-454.

Aid T, Kazantseva A, Piirsoo M, Palm K, Timmusk T. 2007. Mouse and rat BDNF gene structure and expression revisited. J Neurosci Res 85: 525-535.

Bahari-Javan S, Maddalena A, Kerimoglu C, Wittnam J, Held T, Bahr M, Burkhardt S, Delalle I, Kugler S, Fischer A, et al. 2012. HDAC1 regulates fear extinction in mice. J Neurosci 32: 5062-5073.

Baj G, Leone E, Chao MV, Tongiorgi E. 2011. Spatial segregation of BDNF transcripts enables BDNF to differentially shape distinct dendritic compartments. Proc Natl Acad Sci 108: 16813-16818.

Bekinschtein P, Cammarota M, Medina JH. 2014. BDNF and memory processing. Neuropharmacology 76 Pt C: 677-683.
Bimonte-Nelson HA, Francis KR, Umphlet CD, Granholm A-C. 2006. Progesterone reverses the spatial memory enhancements initiated by tonic and cyclic oestrogen therapy in middle-aged ovariectomized female rats. Eur I Neurosci 24: 229-242.

Bjornstrom L, Sjoberg M. 2005. Mechanisms of estrogen receptor signaling: convergence of genomic and nongenomic actions on target genes. Mol Endocrinol 19: 833-842.

Bohacek J, Daniel JM. 2009. The ability of oestradiol administration to regulate protein levels of oestrogen receptor $\alpha$ in the hippocampus and prefrontal cortex of middle-aged rats is altered following long-term ovarian hormone deprivation. J Neuroendocrinol 21: 640-647.

Bohacek J, Bearl AM, Daniel JM. 2008. Long-term ovarian hormone deprivation alters the ability of subsequent oestradiol replacement to regulate choline acetyltransferase protein levels in hippocampus and prefrontal cortex of middle-aged rats. J Neuroendocrinol 20: 1023-1027.

Boulware MI, Weick JP, Becklund BR, Kuo SP, Groth RD, Mermelstein PG. 2005. Estradiol activates group I and II metabotropic glutamate receptor signaling, leading to opposing influences on cAMP response element-binding protein. J Neurosci 25: 5066-5078.

Boulware MI, Heisler JD, Frick KM. 2013. The memory-enhancing effects of hippocampal estrogen receptor activation involve metabotropic glutamate receptor signaling. J Neurosci 33: 15184-15194.

Bousiges O, Vasconcelos AP, Neidl R, Cosquer B, Herbeaux K, Panteleeva I, Loeffler JP, Cassel JC, Boutillier AL. 2010. Spatial memory consolidation is associated with induction of several lysine-acetyltransferase (histone acetyltransferase) expression levels and $\mathrm{H} 2 \mathrm{~B} / \mathrm{H} 4$

acetylation-dependent transcriptional events in the rat hippocampus. Neuropsychopharmacology 35: 2521-2537.

Chapman TR, Barrientos RM, Ahrendsen JT, Hoover JM, Maier SF, Patterson SL. 2012. Aging and infection reduce expression of specific brain-derived neurotrophic factor mRNAs in hippocampus. Neurobiol Aging 33: 832.e1-832.e14.

Chatterjee S, Mizar P, Cassel R, Neidl R, Selvi BR, Mohankrishna DV, Vedamurthy BM, Schneider A, Bousiges O, Mathis C, et al. 2013. A novel activator of $\mathrm{CBP} / \mathrm{p} 300$ acetyltransferases promotes neurogenesis and extends memory duration in adult mice. J Neurosci 33: 10698-10712.

Chwang WB, O’Riordan KJ, Levenson JM, Sweatt JD. 2006. ERK/MAPK regulates hippocampal histone phosphorylation following contextual fear conditioning. Learn Mem 13: 322-328.

Dagnas M, Mons N. 2013. Region- and age-specific patterns of histone acetylation related to spatial and cued learning in the water maze. Hippocampus 23: 581-591.

Daniel JM, Hulst JL, Berbling JL. 2006. Estradiol replacement enhances working memory in middle-aged rats when initiated immediately after ovariectomy but not after a long-term period of ovarian hormone deprivation. Endocrinology 147: 607-614.

Dos Santos Sant' Anna G, Rostirola Elsner V, Moyses F, Reck Cechinel L, Agustini Lovatel G, Rodrigues Siqueira I. 2013. Histone deacetylase activity is altered in brain areas from aged rats. Neurosci Lett 556: $152-154$.

Fan L, Zhao Z, Orr PT, Chambers CH, Lewis MC, Frick KM. 2010. Estradiol-induced object memory consolidation in middle-aged female mice requires dorsal hippocampal extracellular signal-regulated kinase and phosphatidylinositol 3-kinase activation. J Neurosci 30: 4390-4400.

Fernandez SM, Frick KM. 2004. Chronic oral estrogen affects memory and neurochemistry in middle-aged female mice. Behav Neurosci 118: $1340-1351$.

Fernandez SM, Lewis MC, Pechenino AS, Harburger LL, Orr PT, Gresack JE, Schafe GE, Frick KM. 2008. Estradiol-induced enhancement of object memory consolidation involves hippocampal ERK activation and membrane-bound estrogen receptors. J Neurosci 28: 8660-8667.

Fischer A, Sananbenesi F, Mungenast A, Tsai LH. 2010. Targeting the correct HDAC(s) to treat cognitive disorders. Trends Pharmacol Sci 31: $605-617$.

Fortress AM, Schram SL, Tuscher JJ, Frick KM. 2013a. Canonical Wnt signaling is necessary for object recognition memory consolidation. I Neurosci 33: 12619-12626.

Fortress AM, Fan L, Orr PT, Zhao Z, Frick KM. 2013b. Estradiol-induced object recognition memory consolidation is dependent on activation of mTOR signaling in dorsal hippocampus. Learn Mem 20: 147-155.

Frick KM, Gresack JE. 2003. Sex differences in the behavioral response to spatial and object novelty in adult C57BL/6 mice. Behav Neurosci 117: $1283-1291$.

Frick KM, Burlingame LA, Arters JA, Berger-Sweeney J. 2000. Reference memory, anxiety, and estrous cyclicity in C57BL/6NIA mice are affected by age and sex. Neuroscience 95: 293-307.

Frye CA, Duffy CK, Walf AA. 2007. Estrogens and progestins enhance spatial learning of intact and ovariectomized rats in the object placement task. Neurobiol Learn Mem 88: 208-216. 
Fuchikami M, Yamamoto S, Morinobu S, Takei S, Yamawaki S. 2010. Epigenetic regulation of BDNF gene in response to stress. Psychiatry Investig 7: 251-256.

Gibbs RB. 1998. Levels of trkA and BDNF mRNA, but not NGF mRNA, fluctuate across the estrous cycle and increase in response to acute hormone replacement. Brain Res 787: 259-268.

Graff J, Tsai LH. 2013a. Histone acetylation: molecular mnemonics on the chromatin. Nat Rev Neurosci 14: 97-111.

Graff J, Tsai LH. 2013b. The potential of HDAC inhibitors as cognitive enhancers. Аппи Rev Pharmacol Toxicol 53: 311-330.

Graff J, Rei D, Guan JS, Wang WY, Seo J, Hennig KM, Nieland TJ, Fass DM, Kao PF, Kahn M, et al. 2012. An epigenetic blockade of cognitive functions in the neurodegenerating brain. Nature 483: 222-226.

Guan JS, Haggarty SJ, Giacometti E, Dannenberg JH, Joseph N, Gao J, Nieland TJ, Zhou Y, Wang X, Mazitschek R, et al. 2009. HDAC2 negatively regulates memory formation and synaptic plasticity. Nature 459: $55-60$.

Haettig J, Stefanko DP, Multani ML, Figueroa DX, McQuown SC, Wood MA. 2011. HDAC inhibition modulates hippocampus-dependent long-term memory for object location in a CBP-dependent manner. Learn Mem 18: $71-79$.

Harte-Hargrove LC, Maclusky NJ, Scharfman HE. 2013. Brain-derived neurotrophic factor-estrogen interactions in the hippocampal mossy fiber pathway: Implications for normal brain function and disease. Neuroscience 239: 46-66.

Hawk JD, Florian C, Abel T. 2011. Post-training intrahippocampal inhibition of class I histone deacetylases enhances long-term object-location memory. Learn Mem 18: 367-370.

Heldt SA, Stanek L, Chhatwal JP, Ressler KJ. 2007. Hippocampus-specific deletion of BDNF in adult mice impairs spatial memory and extinction of aversive memories. Mol Psychiatry 12: 656-670.

Inagaki T, Frankfurt M, Luine V. 2012. Estrogen-induced memory enhancements are blocked by acute bisphenol A in adult female rats: role of dendritic spines. Endocrinology 153: 3357-3367.

Kenney JW, Poole RL, Adoff MD, Logue SF, Gould TJ. 2012. Learning and nicotine interact to increase CREB phosphorylation at the jnk1 promoter in the hippocampus. PLoS One 7: e39939.

Kessler RC, Chiu WT, Demler O, Merikangas KR, Walters EE. 2005. Prevalence, severity, and comorbidity of 12-month DSM-IV disorders in the National Comorbidity Survey Replication. Arch Gen Psychiatry 62: 617-627.

Kilgore M, Miller CA, Fass DM, Hennig KM, Haggarty SJ, Sweatt JD, Rumbaugh G. 2010. Inhibitors of class 1 histone deacetylases reverse contextual memory deficits in a mouse model of Alzheimer's disease. Neuropsychopharmacology 35: 870-880.

Koppel I, Timmusk T. 2013. Differential regulation of Bdnf expression in cortical neurons by class-selective histone deacetylase inhibitors. Neuropharmacology 75: 106-115.

Levenson JM, O'Riordan KJ, Brown KD, Trinh MA, Molfese DL, Sweatt JD. 2004. Regulation of histone acetylation during memory formation in the hippocampus. J Biol Chem 279: 40545-40559.

Lubin FD, Roth TL, Sweatt JD. 2008. Epigenetic regulation of BDNF gene transcription in the consolidation of fear memory. J Neurosci 28: 10576-10586.

Luine V, Frankfurt M. 2013. Interactions between estradiol, BDNF and dendritic spines in promoting memory. Neuroscience 239: $34-45$.

Luine VN, Jacome LF, Maclusky NJ. 2003. Rapid enhancement of visual and place memory by estrogens in rats. Endocrinology 144: $2836-2844$.

Markham JA, Pych JC, Juraska JM. 2002. Ovarian hormone replacement to aged ovariectomized female rats benefits acquisition of the Morris water maze. Horm Behav 42: 284-293.

Markowska AL. 1999. Sex dimorphisms in the rate of age-related decline in spatial memory: relevance to alterations in the estrous cycle. J Neurosci 19: $8122-8133$.

McQuown SC, Barrett RM, Matheos DP, Post RJ, Rogge GA, Alenghat T, Mullican SE, Jones S, Rusche JR, Lazar MA, et al. 2011. HDAC3 is a critical negative regulator of long-term memory formation. J Neurosci 31: $764-774$.

Milner TA, McEwen BS, Hayashi S, Li CJ, Reagan LP, Alves SE. 2001. Ultrastructural evidence that hippocampal $\alpha$ estrogen receptors are located at extranuclear sites. J Comp Neurol 429: 355-371.

Milner TA, Ayoola K, Drake CT, Herrick SP, Tabori NE, McEwen BS, Warrier S, Alves SE. 2005. Ultrastructural localization of estrogen receptor $\beta$ immunoreactivity in the rat hippocampal formation. J Comp Neurol 491: 81-95.

Murphy DD, Cole NB, Segal M. 1998a. Brain-derived neurotrophic factor mediates estradiol-induced dendritic spine formation in hippocampal neurons. Proc Natl Acad Sci 95: 11412-11417.

Murphy DD, Cole NB, Greenberger V, Segal M. 1998b. Estradiol increases dendritic spine density by reducing GABA neurotransmission in hippocampal neurons. J Neurosci 18: 2550-2559.
Nanda SA, Mack KJ. 2000. Seizures and sensory stimulation result in different patterns of brain derived neurotrophic factor protein expression in the barrel cortex and hippocampus. Brain Res Mol Brain Res 78: $1-14$.

Nott A, Watson PM, Robinson JD, Crepaldi L, Riccio A. 2008. $S$-Nitrosylation of histone deacetylase 2 induces chromatin remodelling in neurons. Nature 455: 411-415.

Packard MG, Teather LA. 1997a. Intra-hippocampal estradiol infusion enhances memory in ovariectomized rats. Neuroreport 8: 3009-3013.

Packard MG, Teather LA. 1997b. Posttraining estradiol injections enhance memory in ovariectomized rats: cholinergic blockade and synergism. Neurobiol Learn Mem 68: 172-188.

Peixoto L, Abel T. 2013. The role of histone acetylation in memory formation and cognitive impairments. Neuropsychopharmacology 38: $62-76$.

Peleg S, Sananbenesi F, Zovoilis A, Burkhardt S, Bahari-Javan S, Agis-Balboa RC, Cota P, Wittnam JL, Gogol-Doering A, Opitz L, et al. 2010. Altered histone acetylation is associated with age-dependent memory impairment in mice. Science 328: 753-756.

Perovic M, Tesic V, Mladenovic Djordjevic A, Smiljanic K, Loncarevic-Vasiljkovic N, Ruzdijic S, Kanazir S. 2013. BDNF transcripts, proBDNF and proNGF, in the cortex and hippocampus throughout the life span of the rat. Age (Dordr) 35: 2057-2070.

Pluchino N, Russo M, Santoro AN, Litta P, Cela V, Genazzani AR. 2013. Steroid hormones and BDNF. Neuroscience 239: 271-279.

Rudick CN, Gibbs RB, Woolley CS. 2003. A role for the basal forebrain cholinergic system in estrogen-induced disinhibition of hippocampal pyramidal cells. J Neurosci 23: $4479-4490$.

Sarkar SN, Huang RQ, Logan SM, Yi KD, Dillon GH, Simpkins JW. 2008. Estrogens directly potentiate neuronal L-type $\mathrm{Ca}^{2+}$ channels. Proc Natl Acad Sci 105: 15148-15153.

Sato K, Akaishi T, Matsuki N, Ohno Y, Nakazawa K. 2007. $\beta$-Estradiol induces synaptogenesis in the hippocampus by enhancing brain-derived neurotrophic factor release from dentate gyrus granule cells. Brain Res 1150: 108-120.

Scharfman HE, Mercurio TC, Goodman JH, Wilson MA, MacLusky NJ 2003. Hippocampal excitability increases during the estrous cycle in the rat: a potential role for brain-derived neurotrophic factor. J Neurosci 23: $11641-11652$

Schwartz N, Schohl A, Ruthazer ES. 2011. Activity-dependent transcription of BDNF enhances visual acuity during development. Neuron 70: 455-467.

Sharma SK. 2010. Protein acetylation in synaptic plasticity and memory. Neurosci Biobehav Rev 34: 1234-1240.

Singh M, Meyer EM, Simpkins JW. 1995. The effect of ovariectomy and estradiol replacement on brain-derived neurotrophic factor messenger ribonucleic acid expression in cortical and hippocampal brain regions of female Sprague-Dawley rats. Endocrinology 136: $2320-2324$.

Sohrabji F, Miranda RC, Toran-Allerand CD. 1995. Identification of a putative estrogen response element in the gene encoding brain-derived neurotrophic factor. Proc Natl Acad Sci 92: 11110-11114.

Spencer JL, Waters EM, Milner TA, McEwen BS. 2008a. Estrous cycle regulates activation of hippocampal Akt, LIM kinase, and neurotrophin receptors in C57BL/ 6 mice. Neuroscience 155: 1106-1119.

Spencer JL, Waters EM, Romeo RD, Wood GE, Milner TA, McEwen BS. 2008b. Uncovering the mechanisms of estrogen effects on hippocampal function. Front Neuroendocrinol 29: 219-237.

Srivastava DP, Woolfrey KM, Jones KA, Shum CY, Lash LL, Swanson GT, Penzes P. 2008. Rapid enhancement of two-step wiring plasticity by estrogen and NMDA receptor activity. Proc Natl Acad Sci 105: $14650-14655$

Stefanko DP, Barrett RM, Ly AR, Reolon GK, Wood MA. 2009. Modulation of long-term memory for object recognition via HDAC inhibition. Proc Natl Acad Sci 106: 9447-9452.

Tao X, Finkbeiner S, Arnold DB, Shaywitz AJ, Greenberg ME. 1998. Ca ${ }^{2}$ influx regulates BDNF transcription by a CREB family transcription factor-dependent mechanism. Neuron 20: 709-726.

Towart LA, Alves SE, Znamensky V, Hayashi S, McEwen BS, Milner TA. 2003 Subcellular relationships between cholinergic terminals and estrogen receptor- $\alpha$ in the dorsal hippocampus. J Comp Neurol 463: 390-401.

Vecsey CG, Hawk JD, Lattal KM, Stein JM, Fabian SA, Attner MA, Cabrera SM, McDonough CB, Brindle PK, Abel T, et al. 2007. Histone deacetylase inhibitors enhance memory and synaptic plasticity via CREB:CBP-dependent transcriptional activation. J Neurosci 27: $6128-6140$

Walf AA, Rhodes ME, Frye CA. 2006. Ovarian steroids enhance object recognition in naturally cycling and ovariectomized, hormone-primed rats. Neurobiol Learn Mem 86: 35-46.

Wang W, Li S, Dong HP, Lv S, Tang YY. 2009. Differential impairment of spatial and nonspatial cognition in a mouse model of brain aging. Life Sci 85: $127-135$. 
Wimmer ME, Hernandez PJ, Blackwell J, Abel T. 2012. Aging impairs hippocampus-dependent long-term memory for object location in mice. Neurobiol Aging 33: 2220-2224.

Wu TW, Wang JM, Chen S, Brinton RD. 2005. 17ß-Estradiol induced $\mathrm{Ca}^{2+}$ influx via L-type calcium channels activates the Src/ERK/cyclic-AMP response element binding protein signal pathway and BCL-2 expression in rat hippocampal neurons: a potential initiation mechanism for estrogen-induced neuroprotection. Neuroscience 135: $59-72$.

Yaffe K, Barnes D, Lindquist K, Cauley J, Simonsick EM, Penninx B, Satterfield S, Harris T, Cummings SR. 2007. Endogenous sex hormone levels and risk of cognitive decline in an older biracial cohort. Neurobiol Aging 28: $171-178$.

Yamaguchi-Shima N, Yuri K. 2007. Age-related changes in the expression of ER- $\beta$ mRNA in the female rat brain. Brain Res 1155: $34-41$.

Yang X. 2007. HATs and HDACs: from structure, function and regulation to novel strategies for therapy and prevention. Oncogene 26: 5310-5318.

Zandi PP, Carlson MC, Plassman BL, Welsh-Bohmer KA, Mayer LS, Steffens DC, Breitner JCS. 2002. Hormone replacement therapy and incidence of Alzheimer disease in older women. JAMA 288: 2123-2129.

Zeng Y, Tan M, Kohyama J, Sneddon M, Watson JB, Sun YE, Xie CW. 2011. Epigenetic enhancement of BDNF signaling rescues synaptic plasticity in aging. J Neurosci 31: 17800-17810.
Zhao L, Chen S, Ming Wang J, Brinton RD. 2005. 17 $\beta$-Estradiol induces $\mathrm{Ca}^{2+}$ influx, dendritic and nuclear $\mathrm{Ca}^{2+}$ rise and subsequent cyclic AMP response element-binding protein activation in hippocampal neurons: a potential initiation mechanism for estrogen neurotrophism. Neuroscience 132: 299-311.

Zhao Z, Fan L, Frick KM. 2010. Epigenetic alterations regulate the estradiol-induced enhancement of memory consolidation. Proc Natl Acad Sci 107: 5605-5610.

Zhao Z, Fan L, Fortress AM, Boulware MI, Frick KM. 2012. Hippocampal histone acetylation regulates object recognition and the estradiol-induced enhancement of object recognition. J Neurosci 32: $2344-2351$.

Zheng F, Zhou X, Luo Y, Xiao H, Wayman G, Wang H. 2011. Regulation of brain-derived neurotrophic factor exon IV transcription through calcium responsive elements in cortical neurons. PLoS One 6: e28441.

Zheng F, Zhou X, Moon C, Wang H. 2012. Regulation of brain-derived neurotrophic factor expression in neurons. Int J Physiol Pathophysiol Pharmacol 4: 188-200.

Zhou Y, Watters JJ, Dorsa DM. 1996. Estrogen rapidly induces the phosphorylation of the cAMP response element binding protein in rat brain. Endocrinology 137: 2163-2166.

Received December 4, 2013; accepted in revised form June 24, 2014. 


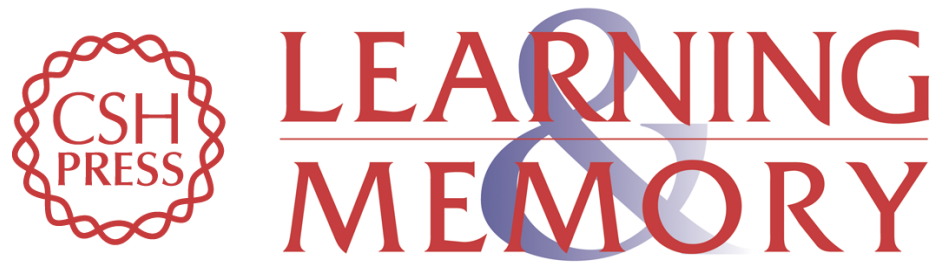

\section{$17 \beta$-Estradiol regulates histone alterations associated with memory consolidation and increases $B d n f$ promoter acetylation in middle-aged female mice}

Ashley M. Fortress, Jaekyoon Kim, Rachel L. Poole, et al.

Learn. Mem. 2014, 21:

Access the most recent version at doi:10.1101//m.034033.113

References This article cites 91 articles, 29 of which can be accessed free at: http://learnmem.cshlp.org/content/21/9/457.full.html\#ref-list-1

Creative This article is distributed exclusively by Cold Spring Harbor Laboratory Press for the Commons first 12 months after the full-issue publication date (see

License http://learnmem.cshlp.org/site/misc/terms.xhtml). After 12 months, it is available under a Creative Commons License (Attribution-NonCommercial 4.0 International), as described at http://creativecommons.org/licenses/by-nc/4.0/.

Email Alerting Receive free email alerts when new articles cite this article - sign up in the box at the Service top right corner of the article or click here. 